\title{
Hiding in plain sight
}

\section{Print literary histories in the digital age}

\section{G} raduate-level teaching of literature at universities and colleges has changed radically over the past four decades. In an earlier era, literature graduate students typically began their studies with a formulaic sequence of survey courses. The death of the canon was pronounced in the 1960s with the rise of literary theory, which replaced traditional literary history and philology as the backbone of the curriculum. In the process, survey courses were often replaced by open-ended requirements, such as "one course before 1750 and one course after 1750.” As a consequence, today's literature graduate students come to the task of formulating a thesis topic with a broader range of cross-disciplinary interests, but also with widely divergent background knowledge and unpredictable "blind-spots."

At the same time, skills in effective use of the library and information tools have become more difficult for students to acquire unaided. In earlier times, graduate students came to know the library gradually, by spending time with physical objects in the reference room, the index area, the journal area, the stacks, and, eventually in special collections or archives. They handled volumes and made conceptual connections between the resources and the role each served in their discipline. They used print resources in a fairly stereotypical sequence to develop a thesis project.

Today's online environment gives graduate students access to unprecedented volumes of materials. Yet the traditional analog research process fails to translate to this new online environment. The instructional equivalent of "browsing resources" leads (in our experience of mentoring graduate students) to endless clicking, culminating in near-total disorientation. Physical objects, rather than providing a comfortable sense of familiarity, now compete with virtual ones for students' attention, with the disadvantage that working with print media now seems "slow" compared to the promise of near-instantaneous access that online resources dangle before users.

Students now work from two angles. Most still have an inkling of the traditional, bottomup or "analog" search strategy that moves systematically through paper resources and their digital counterparts in ever widening circles to establish the factual and intellectual chronology of the research field. But increasingly—and often as a first step—students use a top-down search strategy consisting of keyword searches across large combined digital files. The top-down search yields a voluminous and diverse evidence base that typically also cuts across subdisciplines.

Each of these two modes can be useful, but building an efficient and effective search in the online environment is radically different from the older, bottom-up search model. Today's students must know when to use each, and library instruction must pay attention to both approaches.

Finally, and paradoxically, even as the availability of online resources has exploded, we have been impressed by how profoundly

Heidi Madden is librarian for Western European Studies and Medieval Renaissance Studies/adjunct assistant professor of German Studies, e-mail: heidi.madden@ duke.edu, and Ann Marie Rasmussen is professor in the Department of Germanic Languages and Literature at Duke University, e-mail:annmarie.rasmussen@duke.edu (c) 2013 Heidi Madden and Ann Marie Rasmussen 
students can be moved by encounters with real physical books and artifacts. As you read this article, consider what it might be like for a student accustomed to staring into a laptop screen to sit, white-gloved, around a table with colleagues in a quiet, dimmed room, carefully turning the pages of a volume, seeing the bright, clear colors and the exquisitely balanced graphic layout of facing pages; hearing the gentle creaking of the binding, the crackle of its heavy pages and the rustle of rice paper veiling the images; smelling its faint old-book mustiness mixed with a hint of inky tang; hefting its weight, touching each page, furtively brushing the raised letters. The print collection of a modern research library continues to offer unique opportunities for experiential learning.

\section{A new graduate survey course}

The Carolina-Duke Program in German Studies reintroduced two required survey courses in 2009. "Cultural Foundations in German Studies, 1150-1815" was taught for the first time in 2010. ${ }^{1}$ The Western European Studies librarian was integrated into course planning and design. Libraries present entry points to their complex holdings by providing "Library Research Guides" to help students internalize some knowledge of standard resources in their field.

Duke Library offered such a guide to "Cultural Foundations in German Studies"; included lists of standard catalogs, databases, books, and journals. Yet faculty and graduate students did not find these lists immediately useful; they expressed a desire for a different library learning experience. Working collaboratively, the faculty members and librarian realized that they wanted to deliver an integrated library and research experience where "searching" and "researching," reading the records and conceptualizing the genealogy of ideas, themes, and schools (i.e. chronology), were an interrelated process. Faculty also realized that graduate students generally assumed that most, if not all, of the knowledge, information, and scholarship they needed would be in digital format. Students were almost entirely unaware of, and not using, that old standby of literary scholarship and chronology, the classic print literary history. What was needed was a focus on teaching literacies, both those that were discipline specific (like chronology) as well as general information literacies. ${ }^{3}$

\section{Literary histories: Hidden in plain sight}

It is commonplace knowledge that monographic sets and series pose challenges in cataloging and corresponding challenges in online searching. It is also apparent that national literary histories are narrated in monographic sets and series. This combination of research topic (chronology in national literary history) and library skill (online searching and analysis of results) became the basis of the instructional design. We created two assignments that were embedded in the larger course. ${ }^{4}$

The first library assignment was designed to help students develop assurance with research tools. Students were asked to update and annotate title entries from the "German Studies Library Research Guide" for literary history titles in a GoogleDoc. They were asked to double-check the accuracy of the volume information, correct errors, add publication information as needed, and write a pithy, descriptive two- to three-sentence summary of the resource. They worked with the actual volumes in the stacks and in Special Collections, thumbing through their tables of contents, the indexes, and chapters.

The following example from the list of literary histories has a simple enough title, corresponding perhaps to its status as the standard West German literary history: Helmut de Boor and Richard Newald, Geschichte der deutschen Literatur von den Anfängen bis zur Gegenwart, Volume 1-12, (München: Beck, 1949). However, the process of putting together the set in online searches and on the shelf lead to some alarming and surprising discoveries.

A search for the title Geschichte der deutschen Literaturvon den Anfängen bis zur Gegenwart in WorldCat brings 1,664 results. This is an overwhelming number for students (and faculty!). The set was designed to cover the history of German literature from the years 770 to the present in 12 volumes. Volumes 3, 
4, 7, and 9 are multivolume works each with their own additional subseries title; the set is also cataloged with a variant series title of Handbücher für das germanistische Studium. Volume 6 was intended as a two-volume set, where volume 6/1 was published as Von Klopstock bis zu Goethes Tod: 1750-1832. Ende der Aufklärung und Vorbereitung der Klassik; but volume $6 / 2$ in the original design was never published; the subsequently released onevolume edition of volume 6 was published under the new title Aufklärung, Sturm und Drang, Frübe Klassik (1740-1789). Volume 9 is a two-volume set, but does not have a subseries title, rather, it adopts an identical main entry for both volumes, with two different time periods and a different subtitle: volume 9/1 Geschichte der deutschsprachigen Literatur 1870-1900. Von der Reichsgründung bis zur Jahrhundertwende. and volume 9/2 Geschichte der deutschsprachigen Literatur 1900-1918. Von der Jahrhundertwende bis zum Ende des Ersten Weltkriegs. Volume 8 (1830-1870), volume 10, and volume 11 (1918-1945) have never been published. ${ }^{5}$ Many volumes in the twelve volume set saw multiple editions, up to 11 editions, in fact, and some newer editions of volumes 3 and 7 also have variant titles, i.e., a different title for the later editions.

Faculty and the librarian knew that these volumes existed because they used them when they were graduate students themselves. The shock in this process was realizing that these print literary histories, which contain knowledge not reproduced online, could not be found by novice researchers such as graduate students. The volumes were miscataloged, mislabeled, re-titled and reconceived by the publisher, and incomplete, with sets broken up and scattered in the stacks instead of being together in one place. They were unfindable in the online catalog. These valuable research tools were in plain sight; the library owned all the volumes in the set, but they were effectively hidden.

The second library assignment used a selected list of literary histories of German literature (de Boor/Newald among them) as a source, not for basic facts, but for tracing the changing representations of a work over time. Students selected literary histories to maximize contrast. They created a handout and gave a brief, five-minute presentation exploring how the work had been discussed and canonized in histories of German literature from the early 19th century to the present. Examples of tracings included works by Johann Joachim Winckelmann, Gotthold Ephraim Lessing, Christoffel von Grimmelshausen, Sebastian Brandt, Johannes von Tepl, August von Kotzebue, Walther von der Vogelweide, Johann Gottfried von Herder, Johann Wolfgang von Goethe, Friedrich von Schiller, and Siegfried Lenz.

While the first assignment honed skills in handling complex bibliographic data, the second assignment demonstrated the operating principles of national literary histories: they are not mere collections of facts, they reflect and reveal contemporary society at-large. One student commented that the assignment made him intensely aware of the different styles of language considered scholarly in their time; another noted that it was compelling to follow the changing perceptions of the role played by literature in society and culture, especially the value placed in the 19th century on cultivating literariness itself.

When students examined several editions of Josef Nadler's Literaturgeschichte der deutschen Stämme und Landschaften (editions from the '20s, '30s, and post '45) they discovered that the edition from 1938 to 1941 was completely revised and republished after Nadler joined the NSAPD (Nazi party) in 1938; they also found that the later editions were substantially revised again after 1945, with the fascist ideology and perspective removed. ${ }^{6}$ The Nazi-era edition is an expensive, sumptuously designed and produced set. Nicely bound, it contains fancy paper and fonts, and, on nearly every page, colorful fold-out inserts-reproductions of letters, manuscripts, illustrations, and artwork. The volumes are made to look like an ancient treasure chest, clearly in order to create the impression of the enduring value of "German" identity. Yet reading the text of the Nazi-era edition, one encounters 
its repugnant ideology at every turn. One student remarked that these volumes were a perfect example of the Nazi skill in creating propaganda. If students had searched WorldCat for the latest edition of this work, and not handled the sets of various editions in the original, they would have completely lost this linkage between culture, politics, and representation.

\section{Conclusion}

Individual literary histories may gloss over the historically constructed and contingent nature of knowledge, but read comparatively and in sequence, they are profound witnesses to their own times. Literary histories allow graduate students to be time travelers, as it were, encountering the thoughts and values of each era on its own terms. The physical objects, the actual books, are artifacts that do not merely enhance the learning experience but on the contrary are an integral part of it.

Such a learning experience also requires graduate students to perform their own interpretation and synthesis rather than merely repeating the "canned" historiographies of others. They practice being makers of knowledge, as befits their professional goals, while gaining expertise in the historiography of their field, something that is expected of anyone holding a Ph.D.

These two assignments certainly increased the graduate students' awareness of their own situatedness in time. One student, commenting on the boom in German literary histories in the 1880s and 1890s added as an aside, "It makes you think that when we're the old stalwarts of a German department in 50 years maybe our younger colleagues will say, 'Oh, its that crazy guy with the Welbery approach [the author of a recent German literary history they all liked] from back in the day ..."' Our examples were German, but the assignments scale to all national literatures and will facilitate literacy through experiential learning.

We are creatures of minds and hearts. Our capacity to make memory and build knowledge arises from the enmeshment, the entanglement, of our emotional, physical, and mental selves. In this arena, science and experience meet, telling us the same thing: the abstract and the concrete build on, enhance, and reinforce one another.

\section{Notes}

1. http://carolina-duke-grad.german.duke. edu/, accessed July 6, 2012.

2. http://guides.library.duke.edu/carolina_duke_german, accessed July 6, 2012.

3. "Information literacy competency standards for higher education," www.ala.org /acrl/standards/informationliteracycompetency (accessed July 6, 2012), and "Information literacy in the disciplines," ACRL Wiki, http:// wikis.ala.org/acrl/index.php/Information _literacy_in_the_disciplines (accessed July 10, 2012); for chronology as a literacy, see Kristen Neuschel, "Teaching and the 'Telescoping' of History," French Historical Studies 34, no 1 (2011), 47-58.

4. See syllabus, the assignment text and completed assignments: http://guides.library. duke.edu/foundations_german, accessed July 6, 2012.

5. de Boor, Helmut and Richard Newald, 1949, Geschichte der deutschen Literaturvon den Anfängen bis zur Gegenwart. Vols. I-XII. A summary of volumes in the set is provided at http://guides.library.duke.edu/content. php?pid=338746\&sid=2781173 (accessed July $23,2012)$. Russ Besancon, labeled each volume of a given set with the name of the editor; Amy Turner, recataloged volumes so that they will be together on the shelf; we found yet another volume in the de Boor Newald set at the end of the semester: the 2006 edition of the 12th volume was cataloged under PT 401 .G47 2006, while the rest of the set now resides under PT 85.

6. Josef Nadler, Literaturgeschichte der deutschen Stämme und Landschaften (Regensburg, J. Habbel, 1912-28), and Literatur Geschichte des deutschen Volkes; Dichtung und Schrifttum der deutschen Stämme und Landschaften (Berlin, Im Propyläen-verlag, 1938-1941), and Literaturgeschichte der deutschen Stämme und Landschaften (Darmstadt: Weibert, 1960).n 